\title{
Design Of Visual Display Terminal Paramaters For Visual Comfort And Performance
}

\author{
Hartomo $^{1, a}$, Abdul Djalal $^{2, b}$, Kokoh Kurniawan $^{3, c}$ \\ and Rachmah Nanda Kartika, ${ }^{4, d}$ \\ 1,2,3,4 Work Design Analysis and Ergonomic Laboratory \\ Department of Industrial Engineering \\ Faculty of Industrial Technology, \\ Islamic University of Indonesia, Yogyakarta \\ ahart_tom68@yahoo.com, bkokoh_kurniawan@yahoo.com, drachmahnanda@yahoo.com
}

Keywords: visual display terminal (VDT), Taguchi methods, visual comfort and performances

\begin{abstract}
The purpose of this study is to design the Visual Display Terminal parameters for the visual comfort and high performance. Taguchi's Design of Experiments method was used to determine the optimum level of parameters that consist of external and internal lighting, monitor position angle and eye-to-monitor distance. An experimental study was conducted in Ergonomics laboratory. Typing operation was done as a case study. 15 university students $(7$ males and 8 females) with age range between 21- 26 years old took part. The results of study finds that the optimum external lighting $(\mathrm{A} 1)=1325 \mathrm{Lux}$, the monitor-eye position angle $(\mathrm{B} 2)=15^{\circ}$, The distance vision from eye - monitor $(\mathrm{C} 1)=20$ inches, internal lighting $(\mathrm{D} 1)=60$ Lux. This study has also found that eye blinking decreased about $50 \%$ and the performance increased about $89.76 \%$. Thus, the parameters of VDT can produce better visual comfort and performance.
\end{abstract}

\section{Introduction}

High productivity can be achieved if an operator works comfortably when interacting with the computer. One of the factors affecting the visual comfort is Visual display Terminal (VDT) variables. Visual comfort is determined by the performance of the lighting system such as not dazzling and showing the true colors (Hendrawan, 2003).

A computer operator should complete the task in a short time with good results. In fact, longer time spent working in front of a computer can affect eye comfort, which eventually will result in impairment of the eyes. The hazard of computer use may occur $75 \%-90 \%$ on visual performance. This is caused by light radiation of computer screen as well as electromagnetic waves released by the computer electrical system (in Swamardika NIOSH, 2001).

A fatigue symptom in the eyes is called Computer Vision Syndrome (CVS). The symptoms are blurred vision, dry eye, headache, neck pain, shoulders and back pain. In addition, the use of VDT can cause dry eye syndrome to the workers. Such impaired vision can be caused by boredom; fatigue and eye strain resulting in dizziness, and blurred vision.

Musculoskeletal disorders such as tension in the neck muscles also affect the operators' comfort and performance which accounted for up to 22\% (in Swamardika NIOSH, 2001). Glare disturbances (glare) in the eye has been very disturbing for the operator especially those working in a long duration. It also has a significant influence on the level of precision of the work, increased workload, and ultimately, reduced productivity. Therefore, research on the optimization of the design on computer operator activities is important.

\section{Research Methods}

Taguchi's Method. Taguchi's method combines a statistical and engineering method that was developed by Genichi Taguchi. It aims to improve the performance of computer operators (Belavendram, 1995). This method is to identify various major factors and to set values obtained from the smallest variation based on the empirical study. 
a. Calculation of Signal To Noise Ratio (SNR) is based on objective quality characteristics of the Larger the Better

$$
\mathrm{SNR}=-10 \log \left[\frac{1}{n} \sum_{i=n}^{n}\left(\frac{1}{y_{i}^{2}}\right)\right]
$$

b. Calculation of ANOVA (Analysis of Variance) to estimate the contribution factor of SNR using formula below :

$$
\mathrm{P}=\left[\frac{S S^{\prime}}{S S_{T}}\right] x 100 \%
$$

Where :

$\mathrm{Ss}^{\prime}=$ The pure of square of the factors

$\mathrm{SS}_{\mathrm{T}}=$ Total sum of Square

Then $\mathrm{F}$ test conducted to test the hypothesis;

Ho: the factors do not affect the process

$\mathrm{H} 1$ : the factors affect the process

The effect for each factor can be estimated by formula as follows :

Where:

$$
\text { Effect factor }=\frac{1}{a}\left(\sum \eta_{0}\right)
$$

$0=$ number of experiments that would have the same level.

$\mathrm{a}=$ number of appearance of each level factor in an orthogonal matrix.

$\eta=$ using SNR.

e. Confirmation of experimental results.

Subjects. Subjects were fifteen university students who were familiar with the typing task using the computer. Their age ranges between $21-26$ years old. All subjects were identified as having no visual problem. Table 1 presented anthropometrics data of subject.

Table 1. Anthropometric data of subject

\begin{tabular}{|c|c|c|c|c|c|c|c|c|}
\hline \multirow{2}{*}{ Sex } & \multicolumn{2}{|c|}{ Mean } & \multicolumn{2}{c|}{ SD } & \multicolumn{2}{c|}{ Min } & \multicolumn{2}{c|}{ Max } \\
\cline { 2 - 9 } & Age & Height & Age & Height & Age & Height & Age & Height \\
\hline Males N=7 & 23 & 170 & 1,69 & 2,93 & 21 & 166 & 26 & 175 \\
\hline Females N=8 & 21,5 & 160,375 & 1 & 3,31 & 21 & 155 & 24 & 165 \\
\hline
\end{tabular}

Apparatus. A climate chamber was used in this experiment to reduce noise from outside. Several tools, such as lux-meter, stopwatch, meter rolls, protractor, and observation sheet were used to measure some variables.

\section{Experimental Design And Procedures}

Design of experiment. The computer operators were instructed to complete a typing task for 15 minutes under a combination of controlled variables such as external lighting, monitor position, visibility and internal illumination. The task is a manuscript typing. The result was a score of typing in the range between 0-1000. The experiment was carried out 32 times for each computer operator with two replications in the climate chamber ergonomic laboratory. Adjustments were performed on the room lighting (external) which contained two fluorescent lights right above the operators and four fluorescent lamps located in the four corner of the room. The internal lighting (monitor) was also adjusted in brightness level from 60 to 70 lux. The eye-to-monitor distance and the eye-to- 
monitor viewing angle follow the combinations specified by Taguchi's Design of Experiment (DOE). Table 2 and Table 3 show the variable of factor level and level of noise factor. The distance of the eye in general.

Table 2. Variable of Factors-Level

\begin{tabular}{|l|c|c|}
\hline Controlled Factors & Level 1 & Level 2 \\
\hline A: External Lighting (Lux) & 325 & 500 \\
\hline B: Position Monitor tilt angle - Eyes $\left(^{\circ}\right)$ & 0 & 15 \\
\hline C: Eye Visibility - Monitor (inches) & 20 & 26 \\
\hline D: Internal Illumination (Lux) & 60 & 70 \\
\hline
\end{tabular}

Table 3. Level of noise factors

\begin{tabular}{|l|c|c|}
\hline \multirow{2}{*}{ Noise factor } & \multicolumn{2}{c|}{ Level } \\
\cline { 2 - 3 } & 1 & 2 \\
\hline E. Time & Morning & Afternoon \\
\hline F. Gender & Male & Female \\
\hline
\end{tabular}

Procedures. The experimental procedure is divided into two phases, namely experiment planning and execution phases. The planning phase included the following steps:

1. Identification and selection the factors that may affect the value of computer typing.

The factors were considered as independent variables in the quality characteristics of the typing true value like the indoor lighting, the light emitted from the computer monitor, eyemonitor visibility, and angle of the eye to monitor position.

2. The defining and separating of the controllable and uncontrollable factors and the noise factors.

In this step, the factors that may affect the quality characteristics were divided into two groups; control and noise factor.

Control factors in this experiment and the reason of selection were:

a. External lighting (lighting coming from the room lights), could be changed as needed.

b. The angle of monitor to eye position.

c. Visibility distance of eyes to monitor.

d. Internal lighting (lighting that comes from the computer monitor).

The involved noise factor in this study and the reason of selection were as follows:

a. The time that was divided into two periods, namely morning (07:00 to 11:00) and afternoon (13:00 to 17:00).

b. The gender, consisting male and female students.

3. Selection of levels or stages of each factor, including control factors and noise factors used in the experiment.

4. Selection of orthogonal matrix (orthogonal array) and assignment of the factors into the orthogonal matrix. Selection of orthogonal matrix includes inner and outer arrays. In this study, it involved two factors of noise, each of which consisting of 2 levels/standards to obtain orthogonal design matrix that was written as the L4 standard. It was considered as the outer array.

5. The characteristics of selection were measured using organoleptic test to determine a dependent variable.

There was only one dependent variable in the study, namely the value of correct typing. The test was done with hedonic organoleptic test using the order of panelists' success. The target oriented quality used the principle; the larger value is the better. 
Implementation of computer typing was conducted through the following stages:

a. Tests were conducted using the hedonic test where the researchers would score the panelists based on the correct typing results with the following rate:

$5=$ Very Good

$4=$ Good

$3=$ enough

$2=$ Good enough

$1=$ Not Good

b. The operators trained were 15 people. They were university students tested by their typing skills earlier.

The instrument to provide the outcome scores were obtained from the combination of orthogonal matrix L8 (inner array) and L4 (outer array).

\section{Results}

Table 4 presented a result of the Taguchi method on the factor levels and effect of response. Optimum factor level was obtained when external lighting (A1) $=1325$ Lux and average effect control of factor $\mathrm{A}$ on level 1 is 3.8691 and the monitor-eye angle $=15^{\circ}$. The Average effect control of factor B on level 2 is 3.8500 , with distance of eye - Monitor $(\mathrm{C} 1)=20$ inches. The control of factor $\mathrm{C}$ on level 1 is 3.8566 , where internal light $(\mathrm{D} 1)=60 \mathrm{Lux}$. The performance improvement is $89.76 \%$, and eye-blinking rate after experiment is $12-18$ times.

Table 4. Factors, levels, and effects

\begin{tabular}{|l|c|c|c|c|}
\hline \multicolumn{1}{|c|}{ Factor } & Level & Value & $\begin{array}{c}\text { Av. effect } \\
\text { response mean }\end{array}$ & $\begin{array}{c}\text { Av. effect } \\
\text { response S/N ratio }\end{array}$ \\
\hline External lighting (A) & 1 & 325 lux & 3.8691 & 11.7263 \\
\hline The monitor - eye angle (B) & 2 & $15^{\circ}$ & 3.8500 & 11.6746 \\
\hline Visibility eye - monitor (C) & 1 & 20 inci & 3.8566 & 11.6908 \\
\hline Internal lighting (D) & 1 & 60 lux & 3.8441 & 11.6576 \\
\hline Performance improvement & \multicolumn{4}{|c|}{$100 \%-10.24 \%=89.76 \%}$. \\
\hline Eye blinking Rate & \multicolumn{3}{|c|}{ After Experiment } \\
\cline { 2 - 5 } & During Experiment & \multicolumn{2}{|c|}{$12-18$ times } \\
\cline { 2 - 5 }
\end{tabular}

\section{Discussion}

The results show that the existing combination factors of level A1, B1, C1 and D1 is at 11.7922. In addition, the calculated optimum $\mu$ is 11.9481 and the percentages $(100 \%-10.24 \%)$ is $89.76 \%$. It means that the overall performance of computer operator is increased by $89.76 \%$.

Re-observation was conducted to the computer operator comfort that encompasses eyestrain after the experiment using Taguchi's method. It obtained a better result because it can reduce eye strain compared to the earlier condition. Eye blinking rate during the experiment without implementing Taguchi's DOE was 25-40 times per minute. But, after implementing Taguchi's DOE, the eye blinking rate was 12-18 times per minute. So, the operators felt more comfortable than before. It can be seen in the graph below: 


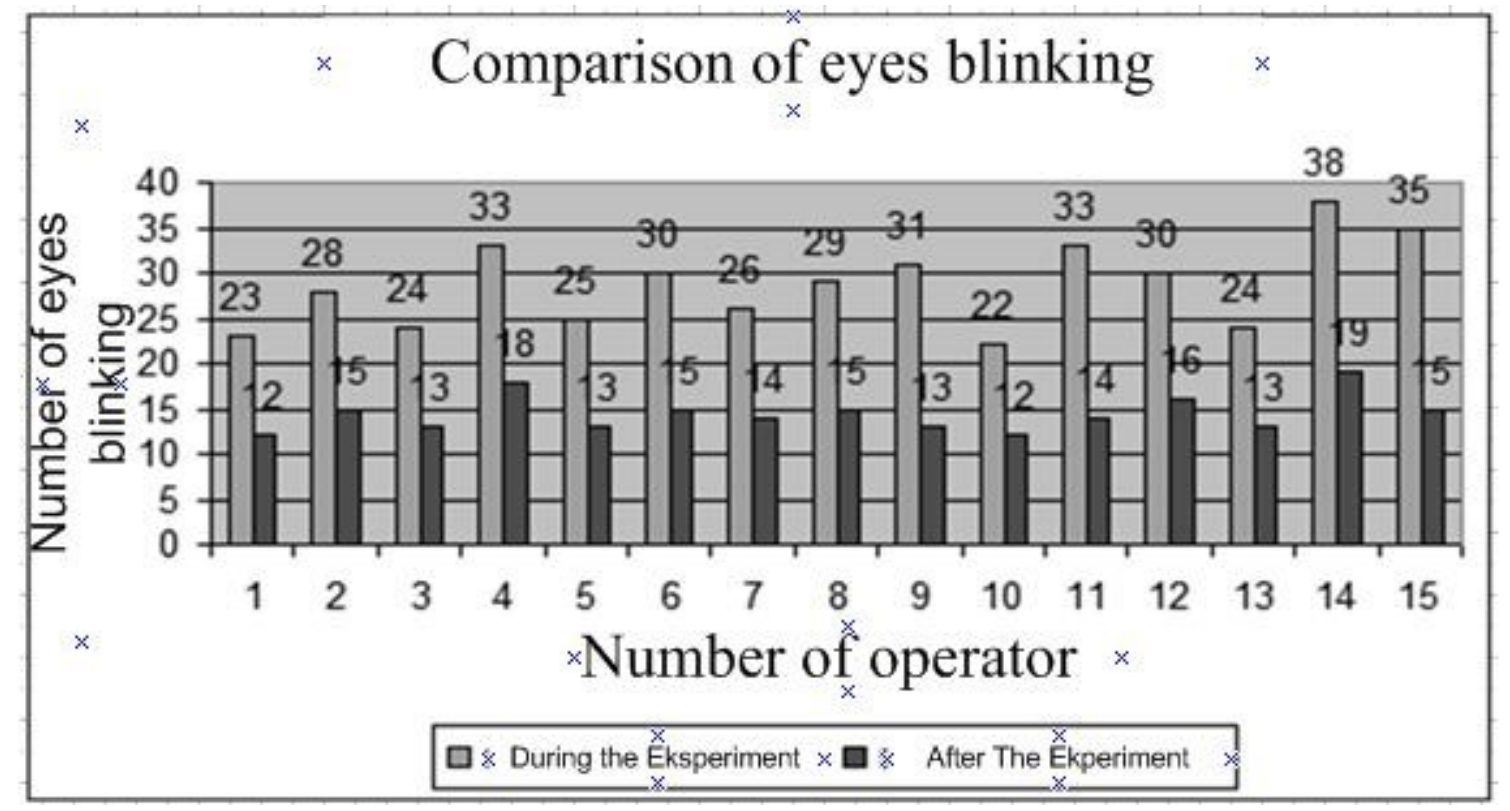

Figure 1. Comparison of eyes blinking

\section{Conclusion}

It can be concluded that:

a. The Set of the optimum parameters of VDT for external lighting is at level 1 (325 Lux) and internal lighting is at level 1 (60 lux).

b. The Set of the optimum parameters of VDT for the angle of the monitor to eye position is at level $2\left(15^{\circ}\right)$, and the distance of eye to monitor is at the level 1 (20 inches).

c. The performance improvement is $89.76 \%$ and the visual comfort improvement is $50 \%$.

\section{References}

[1] Badrie, S., Hermanto, M. Z. Perbaikan Rancangan Produk Yang Memenuhi Kriteria Ergonomis, Seminar Nasional Ergonomi. Yogyakarta.(2004)241-250.

[2] Belavendram, N.Quality By Design-Taguchi Techniques for Industrial Experimentation. Maylands Avenue, UK, Prentice-Hall International, 1995.

[3] Bridger, R. S.Introduction to Ergonomics. Singapura. McGraw-Hill Inc, 1995.

[4] Carayon-Sainfort, P. dan Smith, M. J. Impact of Computer System Performance on Task Characteristics and Worker Stress. Dalam Bullinger, H.J. (Ed.). Proceedings of the Fourth International Conference on Human Computer Interaction. 2. Tokyo : Elsevier. P : 693 698.(1991).

[5] Grandjean, E,Fitting the Task to the Man. $4^{\text {th }}$ ed. London : Taylor \& Francis Inc.(1993).

[6] Harwita, F. E. Pencahayaan dalam Industri. Pelatihan Hiperkes bagi Dokter Perusahaan. Medan : Kanwil Depnakestran Sumatera Utara, 1993.

[7] Hendrawan, A., Suharyana, Kusuma, N. I. Pengaruh Tingkat Pencahayaan Terhadap Kelelahan Kerja Pada Tenaga Akunting Hotel Berbintang di Yogyakarta. Prosiding Seminar Nasional Ergonomi. Yogyakarta. Universitas Gajah Mada, 2003

[8] Lum-i-neering Associates. Lighting Design Handbook. Port Hueneme. Calif : Civil Engineering Laboratory. Dept. of the Navy.(1979).

[9] Manuaba, A. Ergonomi, Kesehatan dan Keselamatan Kerja. Editor : Sritomo Wignyosoebroto dan Stefanus Eko Wiranto. 2000. Prosiding Seminar Nasional Ergonomi 2000. Surabaya : Guna Wijaya. Hal :1-4 (2000). 
[10]Niosh dalam swarmadhika.Penggunaan Filter Layar Monitor Menurunkan Beban kerja dan Meningkatkan Produktivitas Operator Komputer. Jurnal Ergonomi Indonesia. Vol. 2 No. 1. Denpasar: Program Studi Ergonomi-Fisiologi Kerja UNUD. Hal. 20-23.(2001).

[11]Nurmianto, E. Ergonomi, Konsep Dasar dan Aplikasinya. Jakarta. PT Guna Widya. (1996).

[12]Nuswantoro, Y. Analisis Pengaruh Postur Kerja dan Stasiun Kerja Terhadap Kenyamanan Operator Komputer dengan Metode Visual Display Terminal (VDT) Workstation pada Software ErgoEASER. Skripsi S1 Teknik Industri UII Yogyakarta (Unpublished).(2006).

[13] Phesant, S. Ergonomics, Work and Health. London : Mcmillan Press Scientific \& Medical.(1991)

[14] Purbawati. Pengaruh Cahaya Terhadap Waktu Kerja Operator. Prosiding Seminar Nasional Ergonomi. Yogyakarta . Universitas Gajah Mada.(2003).

[15] Purnomo, H., M. Y. Dewantara, R. N. Palilingan. Penilaian Performansi Operator Komputer. Prosiding Seminar Ergonomi. Denpasar. Universitas Udayana.(2006).

[16] Roestijiwati, N.Sindrom Dry Eye pada Pengguna Visual Display Terminal (VDT). Jurnal Cermin Dunia Kedokteran. Jakarta. YARSI. No. 154. (2007).

[17] Sastrowinoto, S. (1985). Meningkatkan Produktivitas dengan Ergonomi. Jakarta. PT. Pustaka Binaman Pressindo.

[18] Suci, C. J.Pengaruh Intensitas Cahaya, Warna Display, dan Jenis Huruf Terhadap Performansi Kerja Operator Komputer. Skripsi S1 Teknik Industri UII Yogyakarta (Unpublished).(2007).

[19] Suma'mur. Norma-norma Penerapan Ergonomi yang Disepakati (The Recomemmended Ergonomic Norms). Jakarta. Pusat Hiperkes Tenaga Kerja.(1986).

[20] Sutalaksana, Iftikar Z. Teknik Tata Cara Kerja. Departemen Teknik Industri. Bandung. ITB.(1979).

[21] Tayyari, F. and Smith, J.L. Occupational Ergonomics, Principles and Applications. London : Chapman \& Hall. (1997)

[22] Wignjosoebroto, S. Ergonomi, Studi Gerak dan Waktu: Teknik Analisis Untuk Meningkatkan Produktivitas Kerja. Surabaya : Guna Widya. (1995)

[23] Woodson, W. E., Tillman, B., and Tillman, P. Human Factors Design Handbook (2 ${ }^{\text {nd }}$ ed.). New York: Mcgraw-Hill.(1991). 